DOI: 10.15503/onis2014-29-34

\title{
Wolność CZY SWAWOLA? STANiSŁaWA KowAlCZYKa KRYTYKa LIBERALIZMU
}

\author{
Patrycja Wałach, coccinelle1@op.pl, \\ Akademia Ignatianum w Krakowie, \\ ul. Kopernika 26, 31-501 Kraków
}

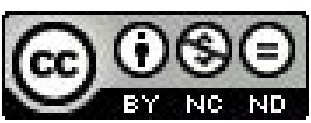

\section{STRESZCZENiE}

Stanisław Kowalczyk, filozof, emerytowany wykładowca Katolickiego Uniwersytetu Lubelskiego, w swoich badaniach wiele miejsca poświęcił filozofii społecznej. Niniejszy artykuł stawia sobie za cel pokazanie tego w jaki sposób lubelski myśliciel dokonuje krytyki liberalizmu z pozycji personalizmu. Przyczyną niezgody między tymi dwoma nurtami jest, jak się okazało, zupełnie inne rozumienie wolności. S. Kowalczyk - personalista, pojmuje wolność jako odpowiedzialne człowieczeństwo, natomiast krytykowany przez niego liberalizm akcentuje przede wszystkim swobodę jednostki.

Słowa kluczowe: filozofia, liberalizm, personalizm, społeczeństwo, wolność

Freedom or wantonness? Stanislaw Kowalczyk's criticism of liberalism

\section{Abstract}

Stanislaw Kowalczyk, philosopher, retired lecturer of the Catholic University of Lublin, in his research work, is very engaged in social philosophy. In this article we aim to show how a thinker from Lublin, as representative of personalism, criticizes liberalism. The cause of disagreement between these streams is,as it turns out, entirely different from idea of freedom. Kowalczyk - personalist interprets freedom as a responsible manhood, whereas liberalism, criticised by him, emphasizes, above all, the liberty of the individual.

Key words: philosophy, liberalism, personalism, society, freedom

Stanisław Kowalczyk jest jednym z reprezentantów personalizmu chrześcijańskiego ${ }^{1}$. Ksiądz, emerytowany profesor Katolickiego Uniwersytetu Lubelskiego, w swoich rozważaniach naukowych bardzo dużo miejsca poświęcił myśli antropologiczno-etycznej. Niniejszy artykuł skupia się przede wszystkim na tym aspekcie twórczości lubelskiego filozofa, który bezpośrednio dotyczy krytyki liberalizmu. Krytyka ta zostaje przeprowadzona przez S. Kowalczyka z pozycji uprawianej przezeń filozofii personalistycznej. W związku z czym wydaje się rzeczą konieczna, aby najpierw przedstawić poglądy niniejszego filozofa i dopiero na takiej podstawie pokazaćjakie zarzuty lubelski uczony kieruje pod adresem ideologii liberalnej.

\section{WOLNOŚĆ WOLI ATRYBUTEM OSOBY}

Personalizm (łac. persona - osoba) jest nurtem filozoficznym, który przypisuje pojęciu osoby ogromne znaczenie. Nieprzypadkowo w tym miejscu pojawia się termin „osoba”, a nie „człowiek”, gdyż dla personalisty to właśnie bycie osobą stanowi swoiste conditio sine qua non odrębności od świata materialnego, podczas gdy termin „człowiek" posiada bardziej biologistyczne konotacje. Człowiek reprezentuje gatunek homo sapiens, osoba natomiast transcenduje widzialną rzeczywistość. Takie rozróżnienie oczywiście nie zmienia faktu, że każdy człowiek jest osobą. W tym wypadku należy jedynie zwrócić uwagę na to, aby przy uwzględnieniu całej cielesności człowieka, jego przynależności do świata materialnego, zauważyć, że tenże człowiek jest osobą - istotą obdarzoną swoistym wnętrzem, kimś a nie czymś. Co więcej, personalizm, choć podkreśla, że o osobowości człowieka świadczy przede wszystkim jego duchowość, to jednocześnie zaznacza, że ciało i dusza są ze sobą nierozerwalnie związane tworząc jeden byt osobowy. Personalizm nie jest spirytualizmem. Osoba to byt duchowo-cielesny, który bez powłoki cielesnej nie mógłby po prostu egzystować. Niemniej jednak to właśnie duchowość, wewnętrzność, która oddziela osobę od reszty stworzonego świata, sprawia, że osoba jest tym, kim jest². S. Kowalczyk, którego myśl zostanie tutaj bliżej nakreślona, stwierdza dobitnie, że „człowiek znajduje się na przecięciu świata

1 Stanisław Kowalczyk (ur.1932) - profesor Katolickiego Uniwersytetu Lubelskiego. Od 1984 r. kierownik Katedry Filozofii Społecznej KUL, dziekan Wydziału Nauk Społecznych KUL (1990-1993), rektor Wyższego Seminarium Duchownego w Sandomierzu (1992-1995).

2 K. Woityła, Osoba i czyn, Lublin 2000, s. 123-133, 242-245.

OGRODY NAUK I SZTUK NR 2014 (4) 
materii i świata ducha: $\mathrm{w}$ świecie zwierząt jest najdoskonalszą istota, w świecie ducha - najniższą" ${ }^{\prime 3}$.

Dla pojęcia osoby cielesność, która skądinąd przysługuje także zwierzętom, nie jest konstytutywna. Zgodnie z tym, co stwierdzono powyżej, o byciu osoba, o jej swoistym esse, świadczy przede wszystkim pierwiastek duchowy. Czym jest ta duchowość? Otóż S. Kowalczyk, kontynuując poglądy dawniejszych mistrzów myśli personalistycznej, za najważniejsze atrybuty osoby uznaje rozumność i wolność. Ze względu na specyfikę poruszanej tematyki, problematyka racjonalności nie zostanie szerzej omówiona, artykuł niniejszy natomiast bardziej postara się przybliżyć personalistyczną koncepcję wolności, która stanowi niejako bazę do ukazania napięcia pomiędzy personalizmem a liberalizmem.

Wolność w ujęciu personalistycznym rozumiana jest jako wolność woli i jako taka stanowi atrybut specyficznie ludzki. Zwierzęta także mogą być wolne, ale tylko w aspekcie fizycznym, nie przysługuje im w żadnym stopniu wolitywność charakterystyczna dla człowieka, a związana z jego bytem duchowym. Filozof z Lublina wolność woli nazywa wolnością ontologiczną i rozróżnia jej dwa wymiary: negatywny i pozytywny. „Wolność woli w sensie negatywnym oznacza brak zewnętrznego czy wewnętrznego przymusu, np. w wyniku psychicznej choroby, narkomanii czy zaawansowanego alkoholizmu" ${ }^{\prime \prime}$. Wolność pozytywna natomiast utożsamiana jest z możliwością wyboru, z decydowaniem o sobie. Dla omawianego filozofa wolność osoby nie kończy się jednak na jej aspekcie pozytywnym. S. Kowalczyk za wolność prawdziwie ludzką uznaje dopiero wolność moralną. O ile wolność negatywna jest „,wolnością od”, o tyle wolność moralna jest zawsze skierowana "„do" realizacji siebie jako osoby ${ }^{7}$. Poprzez dokonywanie różnorodnych wyborów, osoba kształtuje siebie. W zależności od tego ku jakim wartościom się zwróci, może zrealizować siebie bądź dokonać autodestrukcji. Wolność wyboru jest więc podstawą wolności wewnętrznej mającej znaczenie moralne. O ile wolność wyboru może być ograniczona przez czynniki zewnętrzne, o tyle prawdziwa wolność wewnętrzna daje człowiekowi swoistą autonomię względem determinant widzialnej rzeczywistości. Człowiek wewnętrznie wolny to ten, który realizuje w swoim życiu dobro, nieustannie rozwija się duchowo, wyzwala od pokus . „Tej wolności wewnętrznej nie traci człowiek nawet w warunkach zewnętrzno-egzystencjalnych ograniczających skalę wyborów: w więzieniu, chorobie czy perspektywie nieuchronnej śmierci" ${ }^{\prime \prime}$. Ponadto wolność ta jest transcendentna, wychodząca ku prawdziwym wartościom ubogacającym życie ludzkie. Nie jest to wolność dla siebie samej, lecz wolność odpowiedzialna za siebie i innych. Dlatego jej pełna realizacja w życiu każdego człowieka musi zakładać zależność od prawdy o naturze człowieka. Jeśli osoba zacznie działać wbrew temu kim jest, to wtedy popadnie w niewolę różnych, fałszywych bożków, tj. dobra materialne, używki, nastąpi jej swoista reizacja ${ }^{10}$.

Omawiany filozof podkreślając fakt, że wolność woli nie może istnieć poza bytem osobowym, należy bowiem ontycznie do jego struktury, sprzeciwił się zarówno teorii determinizmu, jak i indeterminizmu. Pierwsza z nich zakłada całkowitą zależność człowieka od praw przyrody, druga, przeciwnie, przypisuje osobie niczym nieskrępowane możliwości. S. Kowalczyk stając w opozycji do tak skrajnych ujęć wolności ludzkiej zauważa, że wolność zewnętrzna tylko w pewnym stopniu ograniczana jest przez czynniki empiryczne, nie zaś znoszona, wolność wewnętrzna, jak stwierdzono wyżej, w ogóle nie podlega czynnikom empirycznym ${ }^{11}$. Jeśli chodzi o indeterminizm, to właśnie w tym miejscu wypada nam przyglądną́ się bliżej stosunkowi lubelskiego uczonego do liberalizmu.

\section{LIBERALIZM - JEDNA NAZWA, RÓŻNE ZNACZENIA}

Termin „liberalizm” nie jest jednoznaczny. Jak sama nazwa wskazuje (łac. liber - wolny) jest to nurt myślowy, w centrum którego znajduje się zagadnienie wolności. John Gray, jeden z myślicieli liberalizmu, w reprezentowanym przez siebie kierunku, zauważa pewne spójne i niezmienne cechy. Pomimo niejednoznaczności, a nawet sprzeczności w obrębie samego nurtu, liberalizm, jak stwierdza J. Gray, bazuje na wyraźnie określonej koncepcji człowieka i społeczeństwa. Koncepcja ta jest indywidualistyczna, egalitarna, uniwersalistyczna i meliorystyczna ${ }^{12}$. Pod tymi przydawkami kryją się kolejno odniesienia do indywidualizmu, równości, niezmienności natury ludzkiej oraz do nieustannej możliwości samo-

3 S. Kowalczyk, Kim jest czlowiek?, Wrocław 1992, s. 91.

4 Zob. A. Jabłoński, Stanisława Kowalczyka personalistyczna wizja społeczeństwa, „Roczniki Nauk Społecznych” 2012, 4(40), s. 61.

5 Zob. S. Kowalczyk, Wolność natura i prawem człowieka, Sandomierz 2000, s. 18.

6 Tamże, s. 18.

7 Zob. Tamże, s. 15-19.

8 Zob. Tamże, s. 19.

9 Tamże, s. 19.

10 Zob. Tamże, s. 15-19.

11 Zob. Tamże, s. 14-19.

12 Zob. J. Gray, Liberalizm, Kraków 1994, s. 8. 
doskonalenia tkwiącej w różnych instytucjach społecznych. „,Cztery wspomniane składniki liberalnej koncepcji człowieka i społeczeństwa decydują o jednolitości tradycji liberalnej”'13.

S. Kowalczyk wyszczególnia kilka aspektów liberalizmu jako takiego. Dla niego „liberalizm” może oznaczać „metodę refleksji nad życiem społecznym, sposób kierowania państwem, konkretną partię polityczną czy wreszcie ideologię" ${ }^{\prime \prime 14}$.Jak zaznacza, jego rozważania dotyczą przede wszystkim liberalizmu ideologicznego ${ }^{15}$. Filozof z Lublina nie sprzeciwia się liberalizmowi w jego wymiarze ekonomicznym, czy też politycznym. Takie atrybuty liberalizmu jak choćby: wolny rynek, własność prywatna, czy trójpodział władzy, nie stoją w opozycji do personalistycznej koncepcji człowieka, o ile oczywiście nie godzą w godność osoby. Lubelski filozof krytykuje dopiero liberalizm w jego aspekcie ideologicznym, choć jak zauważa S. Kowalczyk, ten nurt także posiada pewne pozytywne strony, takie jak: „uwypuklanie roli indywidualnego człowieka, postulat respektowania wolności w życiu społecznym, teoria praw człowieka, obrona własności prywatnej, ostra krytyka totalitarnych struktur polityczno-państwowych, dowartościowanie inicjatywy w życiu gospodarczym, wolnego rynku" $^{\prime 16}$. Lubelski uczony zauważa także, że zasady zawarte w Biblii często inspirowały założenia filozofii liberalnej ${ }^{17}$.

\section{NiEOGRANICZONA WOLNOŚĆ JEDNOSTKI}

Liberalizm ideologiczny krytykowany przez S. Kowalczyka, zawiera w sobie wszystkie elementy wymienione przez J. Greya, przy czym ostrze krytyki polskiego uczonego skierowane jest przede wszystkim w indywidualizm. Egalitaryzm, uniwersalizm czy melioryzm są jak najbardziej zgodne z założeniami personalizmu chrześcijańskiego, a to dlatego, że jak zauważa Michael Novak, „,rozróżnienie między ideologią a instytucjami jest jednym z najistotniejszych w katolickiej myśli społecznej” ${ }^{\prime 18}$. Niemniej jednak, należy pamiętać, że instytucjonalizm liberalny, choć na gruncie teorii nie budzi większych zastrzeżeń ze strony personalizmu, to w praktyce może ulec pewnemu wypaczeniu. Dzieje się tak jeśli ideologia ma zbyt duży wpływ na życie polityczne i sektor ekonomiczny. Trudno jednak wymagać, aby aspekt gospodarczy był całkowicie niezależny od nurtu myślowego, z którego nota bene się wywodzi. Pomimo więc rozróżnienia przez lubelskiego filozofa różnych aspektów liberalizmu, i jego pozytywnego odniesienia się do jednych, a krytyki drugich, warto zauważyć, że tak naprawdę liberalizm stanowi spójną całość, w której trudno oddzielić od siebie poszczególne elementy. Praktyka dnia codziennego pokazuje, że założenia ideologiczne nieustannie towarzyszą instytucjom liberalnym. Wspomniane wyżej egalitaryzm, uniwersalizm i melioryzm, teoretycznie mogą być aprobowane przez personalizm, w praktyce jednak dochodzi na tym polu do różnych konfliktów i napięć. Niniejszy artykuł zamierza jednak skoncentrować się na zagadnieniu indywidualizmu, które nierozerwalnie łączy się z koncepcją ludzkiej wolności, i które ab ovo punkt zapalny stawia pomiędzy omawianymi koncepcjami.

Wiadomo, z powyższych rozważań, jak wolność osoby rozumiana jest w filozofii personalistycznej. Otóż, wolność ta jest nieco inaczej pojmowana w liberalizmie. To właśnie różne, wręcz sprzeczne, koncepcje wolności w liberalizmie i personalizmie stanowią rdzeń konfliktu pomiędzy obydwoma nurtami. S. Kowalczyk - personalista, bardzo mocno akcentuje „wolność do"; liberałowie skupiają się, a wręcz ograniczaja, tylko na wolności negatywnej, „wolności od”. Ich punkt widzenia, bardzo dobrze ilustrują następujące słowa wybitnego liberalnego myśliciela, Isaiaha Berlina: „O braku wolności czy też swobód politycznych mówić można jedynie wtedy, gdy realizację celu uniemożliwiają mi inni ludzie" ${ }^{\prime 19}$. Twierdzenie to implikuje istotne wnioski. Po pierwsze widać wyraźnie, że wolność rozumiana jest tutaj stricte negatywistycznie, jako brak przymusu i możliwość robienia tego, czego się pragnie. Po drugie, taka koncepcja wolności izoluje człowieka od społeczeństwa. Inni postrzegani są tutaj jako zagrożenie wolności indywidualnego ,ja”, a nie jako osoby zjednoczone dobrem wspólnym.

Zdaniem S. Kowalczyka wolność postulowana przez liberalizm jest wolnością egocentrycznąi egoistyczną. Przy założeniu, że wszystko mi wolno, nie ma potrzeby uznawania absolutnych wartości moralnych, nierozerwalnie związanych z ludzką naturą. Lubelski myśliciel zwraca uwagę, że ten sposób myślenia tkwi swymi korzeniami w osiemnastowiecznej myśli oświeceniowej, w szczególności w poglądach Thomasa Hobbesa, który „przyjmował (...) teorię psychologicznego

13 Tamże, s. 9 .

14 S. Kowalczyk, Z refleksji nad człowiekiem. Człowiek, spoteczność, wartość, Lublin 1995, s. 187.

15 Początki liberalizmu sięgają XVIII w. Jego głównymi przedstawicielami byli: T. Hobbes, J. J. Rousseau, J. Locke oraz D. Hume. Współcześni zwolennicy tzw. neoliberalizmu (w odróżnieniu od klasycznego) to m.in.: J. Rawls, R. Nozick, I. Berlin

16 S. Kowalczyk, Liberalizm i jego filozofia, Katowice 1995, s. 203.

17 Zob. Tamże, s. 203.

18 M. Novak, Liberalizm - sprzymierzeniec czy wróg Kościoła, Poznań 1991, s. 10.

19 I. Berlin, Cztery eseje o wolności, Poznań 2000, s. 188.

Ogrody NAUK I SZTUK NR 2014 (4) 
egoizmu, widząc w człowieku istotę zdolną wyłącznie do realizacji egoistycznych celów i pragnien'"20. Człowiek, w tym ujęciu, pojmowany jest bardziej jako zwierzę kierujące się instynktami i walczące z innymi o przetrwanie, niż jako rozumna istota otwarta na wartości transcendentne. Niespójność koncepcji wolności w liberalizmie i personalizmie jest więc łatwo zrozumiała. U podstaw tych koncepcji leżą dwie różne antropologie. Personalistyczna „wolność do", realizowania wartości wyższego rzędu wynika z założenia, że człowiek jest osobą obdarzoną niezbywalną godnościa, stworzoną na obraz i podobieństwo samego Boga, i że tylko poprzez działanie zgodne ze swoją rozumną natura, może urzeczywistnić siebie. W liberalizmie, który w swej historii miał liczne konotacje z deizmem $\mathrm{i}$ agnostycyzmem, odwołanie do duchowego wymiaru człowieka traci rację bytu. Skoro bowiem zaneguje się istnienie Absolutu, eo ipso, kierując się logicznymi przesłankami, człowiek nie może być uznawany za imago Dei, za istotę obdarzoną swoistym wnętrzem i wolnością zakorzenioną w prawdzie. Materialistyczny światopogląd przedstawicieli klasycznego liberalizmu nie pozwolił im dostrzec w człowieku czegoś więcej niż tylko jednostkowego , ,ja" dbającego wyłącznie o własne interesy i wygodę ${ }^{21}$.

Lubelski myśliciel stanowczo oponuje przeciw takiemu rozumieniu wolności ludzkiej. Będąc realista, S. Kowalczyk dostrzega w człowieku pewne tendencje egoistyczne, ale jak zauważa, wizja liberalna jest bardzo redukcjonistyczna. Liberalizm nie dostrzega w istocie ludzkiej pewnego spontanicznego nakierowania ku działaniom altruistycznym. Wolność nie polega na robieniu tego, czego się pragnie, lecz na rozumnym obieraniu celów. Taka wolność, paradoksalnie, prowadzić może człowieka do samoograniczania siebie, ale to samoograniczenie nigdy nie krzywdzi osoby, wręcz przeciwnie, jest ono niezbędne do samodoskonalenia siebie, do tego by osoba coraz bardziej stawała się soba, aktualizowała drzemiący w niej potencjał, cechy specyficznie ludzkie ${ }^{22}$. Wolność postulowana przez liberałów tak naprawdę staje się zaprzeczeniem samej siebie. „Kiedy w imię wolności odrzuca się etykę i religię, to skazuje się człowieka na zniewolenie przez bogów immanenencji i natury: kult rozumu, przyjemności, wodza, rasy"23. S. Kowalczyk widzi tutaj jedną z wielu sprzeczności założeń liberalnych. Z jednej strony bowiem nurt gloryfikuje jednostkę i jej wolność, z drugiej natomiast jego antropologia jest ściśle biologistyczna, człowiek nie jest widziany w niej jako suppositum różnorodnych przypadłości, lecz sam niejako stanowi jeden z wielu akcydensów, ,jest pojmowany jako istota, która się staje, stanowiąc zespół interpersonalnych relacji i ciagg aktów psychicznych"24. Taki procesualizm, sprowadzenie osoby do sfery egoistycznych popędów i potrzeb, w gruncie rzeczy jest dla niej obraźliwy, zapoznaje bowiem jej wymiar duchowy, stanowiący conditio sine qua non wszelkiego osobowego esse. Liberalizm czyniąc z jednostki absolut, zniewolił osobę.

\section{SPOŁECZEŃSTWO - DOBRO WSPÓLNE CZY INDYWIDUALNE INTERESY?}

Liberalny kult wolności naturalną koleją rzeczy zaowocował atomistyczną koncepcją społeczeństwa. Skoro każdy człowiek jest egoista, dbającym jedynie o własną wygodę, to ludzie nie są w stanie utworzyć wspólnoty opartej na jakichkolwiek głębszych wartościach i celach. Owszem, to co ich łączy to przede wszystkim „wymiana usług, wzajemne respektowanie swych interesów, sprawna socjotechnika pozbawiona aksjologicznych podstaw" ${ }^{\prime \prime 2}$. Takie myślenie nie jest wytworem współczesnego neoliberalizmu. Już wspomniany wyżej T. Hobbes uznał, że społeczeństwo jest wynikiem umowy społecznej. Ponieważ życie w stanie pierwotnym, nie skażonym cywilizacja, choć naturalne, niosło za sobą mnogość niebezpieczeństw, toteż „ludzie, kierowani chęcią zachowania własnego życia, bezpieczeństwa i własności, zawierają umowę społeczna, czyli tworzą społeczność państwową" ${ }^{\prime 26}$. Społeczeństwo takie powstaje więc na bazie czynników zewnętrznych, takich jak strach czy interesowność, nie jest natomiast wynikiem społecznej natury człowieka.

Warto zauważyć, że w liberalizmie akcentuje się przede wszystkim pojęcie ,,jednostka” a pomija pojęcie „,osoba”. Otóż słowo ,jednostka” bardziej implikuje konotacje aspołeczne, skrajnie indywidualistyczne podczas gdy „osoba" wskazuje raczej na wymiar socjologiczny człowieka, na jego naturalną dążność do bytowania z innymi. Nie znaczy to bynajmniej, że S. Kowalczyk sprzeciwia się wszelkiemu indywidualizmowi, przeciwnie, dla lubelskiego myśliciela, osoba jest zawsze indywiduum, stanowi psychofizyczną jedność i nigdy nie może być traktowana jako część większej całości. Jednakże ta ontyczna separacja od innych bytów sprawia, że osoba, która w pełni jest soba, może otworzyć się na innych ludzi

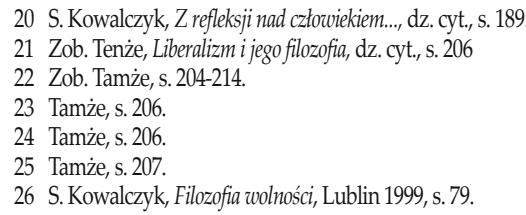


i stworzyć z nimi wspólnotę opartą na wspólnych wartościach ${ }^{27}$. Jak zauważa Arkadiusz Jabłoński, dla omawianego filozofa „Indywidualność wiąże się z nieprzekazywalnościa, czyli niemożnością rezygnacji ze swojej podmiotowości swego bytowego statusu bycia osobą. Atrybuty te łączą się z faktem, że osoba poszukuje innych osób, komunikuje się z nimi i przekazuje im własne doświadczenia oraz wartości"28.

Człowiek żyjąc w społeczeństwie nie traci nic ze swojej wolności, a wręcz ją potwierdza. S. Kowalczyk przypisuje wolności ogromne znaczenie społeczne, a nie, jak to ma miejsce w doktrynie liberalnej, tylko indywidualne. Dla niego osoba nie jest zamkniętą w sobie monada, lecz istotą potrzebującą innych ludzi do swego prawidłowego rozwoju. Skoro jest więc istotą społeczna, to jej decyzje muszą mieć na uwadze dobro wspólne. „Wolność nieegoistyczna jest uczestrictwem w życiu społecznym (...). Odpowiedzialna wolność jest rezultatem samoopanowania i samopodporządkowania się postulatom życia społecznego" ${ }^{\prime \prime 2}$. Jak widać, postulowana przez S. Kowalczyka wolność ma za zadanie służyć dobru wspólnemu wszystkich członków społeczeństwa. Osoba jest bowiem bytem społecznym, a jej wolność najpełniej objawia się w relacjach interpersonalnych ${ }^{30}$.Zupełnie inaczej wolność społeczna ujmowana jest $\mathrm{w}$ doktrynie liberalizmu. Jak już wskazano, liberalizm przede wszystkim koncentruje się na pojęciu jednostki. W myśl ideologii liberalnej to jednostka jest swoistym absolutem, aby jednak każdy mógł spokojnie i wygodnie żyć, potrzeba pewnego minimalnego konsensusu, polegającego na tym, że każdy szanuje interesy drugiego, państwo zaś pełni rolę policjanta strzegącego porządku publicznego. Takie pojmowanie wolności ma charakter stricte minimalistyczny i egocentryczny - pojedyncze ,jal" interesują się tylko własną wolnościa, nie dążą do stworzenia trwałych relacji społecznych, opartych na dobru wspólnym. Co więcej, jeśli uzna się, że społeczeństwo jest luźnym zbiorem jednostek, to trudno nawet mówić o nim jako bycie. W liberalizmie staje się ono czymś przypadłościowym. Optyka S. Kowalczyka jest zgoła inna. Otóż, gdy chodzi o wartości tego samego typu, interesy jednostki żadną miarą nie mogą być przekładane nad dobro ogółu. W drugim przypadku odnoszącym się do wartości ściśle związanych z godnością i osobistą wolnością człowieka, dobro osoby jest priorytetem. Osoba może poświęcić życie za ojczyznę, nigdy zaś dla tej ojczyzny nie może zaprzepaścić własnych zasad. Społeczeństwo zobowiązane jest by chronić wolność swoich członków, wszystkich razem i każdego z osobna ${ }^{31}$.

Widać wyraźnie, że poglądy omawianego uczonego są w ogromnej mierze rozbieżne ze światopoglądem liberalnym. Taki stan rzeczy, należy to podkreślić raz jeszcze, jest naturalną konsekwencją sprzecznych założeń antropologicznych.

\section{RELATYWIZM ZASAD MORALNYCH I INDYFERENTYZM RELIGIJNY}

Ideologia, która tak bardzo podkreśla indywidualizm człowieka, jego niezależność, a wręcz wyalienowanie od społeczeństwa, dla której wolność równoznaczna jest ze swawola, naturaliter implikuje relatywizm aksjologiczny zarówno w życiu prywatnym, jak i społecznym. S. Kowalczyk zwraca uwagę na to, że myśl liberalna dokonuje selekcji zasad moralnych, uznając jedne, a odrzucając drugie. Bez wątpienia obrona wartości takich jak wolnośći prawa każdego człowieka sa, zdaniem filozofa, pozytywnymi aspektami omawianego nurtu. Także afirmacja innowacyjności, pokoju społecznego, rozwoju ekonomicznego, są bezsprzecznymi zaletami liberalizmu. Niemniejjednak pojawiają się także strony negatywne. „Najważniejszym zagrożeniem neoliberalnej teorii moralności jest jej ekstremalny indywidualizm, którego konsekwencją jest subiektywizm oraz relatywizm ${ }^{\prime \prime 32}$. W liberalizmie człowiek przestaje być osobą podległą obiektywnym normom prawa naturalnego, lecz staje się jednostką kreującą zasady na swój własny użytek. Nie to jest dobre, co dobre w sposób niezmienny i stały, lecz to, co w odpowiednim momencie jest dla mnie użyteczne. Utylitaryzm wypiera etykę. S. Kowalczyk za taki stan rzeczy wini liberalny ekonomizm, polegający na prymacie dóbr materialnych nad duchowymi. Liberalna hierarchia wartości jest hierarchią à rebours. S. Kowalczyk dobitnie formułuje swoje stanowisko w tej kwestii: „Sprawiedliwość społeczna nie realizuje się poprzez nieograniczoną wolną konkurencję, lecz wymaga oparcia na ideach solidarności i miłości" ${ }^{\prime \prime 3}$. Etyka postulowana przez liberałów jest, zdaniem filozofa, etyką zdepersonalizowana, oddzieloną od godności osoby, a właściwie to nie jest etyka, lecz raczej pragmatyczną instrukcją jak zapewnić sobie życie o wysokim standardzie materialnym, choć niekoniecznie moralnym.

Lubelski uczony zauważa także, że gloryfikowana przez ideologię liberalną zasada równości, okazuje się być bardzo

27 Zob. Tenże, Liberalizm i jego filozofia, dz. cyt., 159-172.

28 A. Jabłoŕski, Stanistawa Kowalczyka personalistyczna wizja spoteczeństwa, ,, Roczniki Nauk Społecznych" 2012, T. 4(40), nr 1, s. 62.

29 S. Kowalczyk, Człowiek a spoteczność. Zarys filozofii spotecznej, Lublin 1994, s. 171.

30 Zob. Tamże, s. 171.

31 Zob. Tamże, s. 169-173.

32 Tenże, Z reffeksji nad człowiekiem.., dz. cyt., s. 194.

33 Tenże, Liberalizm i jegro filozofia, dz. cyt, s. 209.

Ogrody NAUK I SZTUK NR 2014 (4) 
niebezpieczna. Oczywiście personalizm jak najbardziej zgadza się z twierdzeniem liberałów, że wszyscy ludzie są równi. Wynika to z rozumowego odczytania prawa naturalnego. Problem tkwi jednak gdzie indziej, chodzi bowiem bardziej o równość światopoglądową. Jeżeli w doktrynie liberalnej sądy poszczególnych osób uznawane są za równoważne, to nie można mówić o jednej, stałej i niezmiennej prawdzie. Przy takim założeniu każdy ma swoją prawdę, zasady życia społecznego ulegają relatywizacji.

S. Kowalczyk określa etykę liberalizmu mianem emotywizmu, w myśl którego odkrycie obiektywnych praw rządzących rzeczywistością jest w ogóle niemożliwe, toteż należy zaufać swemu subiektywnemu osądowi. „Emotywizm odrywa zasady etyczne od kontekstu osoby ludzkiej i interpretuje je, opierając się na danych psychologii i socjologii" ${ }^{\prime 34}$. Taka postawa okazuje się być bardzo szkodliwa dla człowieka zarówno w jego wymiarze indywidualnym, jak i społecznym.

Relatywizm moralny liberalizmu nierozerwalnie łączy się z indyferentyzmem religijnym. Religia ulega tutaj „prywatyzacji", staje się osobistą sprawą każdego człowieka, nie zostaje dopuszczona na forum publiczne. S. Kowalczyk zastrzega jednak, że tylko liberalizm europejski jest nieprzychylnie nastawiony do religii, podczas gdy jego amerykański odpowiednik uznaje znacznie sfery sacrum w życiu publicznym. Liberalizm europejski, opierając się na zdobyczach Rewolucji Francuskiej, postuluje neutralność zarówno wobec wiary, jak i ateizmu, religia, w tym chrześcijaństwo nie jest oficjalnie negowana, lecz zepchnięta w sferę prywatnych wyborów człowieka. S. Kowalczyk zarzuca liberałom w tym miejscu brak konsekwencji: „faktycznie bowiem klasyczny liberalizm i współczesny neoliberalizm, nawiązując do tradycji Oświecenia, kontynuują takie elementy, jak epistemologiczny sceptycyzm, etyczny relatywizm, ignorowanie prawa naturalnego, duch naturalizmu i sekularyzmu" ${ }^{\prime \prime 3}$. Działania liberałów w praktyce nie są więc obojętne religijnie, a bardzo często względem niej opozycyjne. „Propagowana przez nich idea neutralności światopoglądowej jest faktycznie upowszechnieniem postaw antychrześcijańskich przy wykorzystaniu instytucji pozostających w dyspozycji państwa"36.

\section{Podsumowanie}

Krytyka S. Kowalczyka skierowana w stronę myśli liberalnej, została przeprowadzona z pozycji personalizmu chrześcijańskiego. Pomimo niewątpliwych zalet, liberalizm, zdaniem omawianego filozofa, prowadzi nieuchronnie do depersonalizacji osoby. Co więcej, sam liberalizm wikła się w swych założeniach. Głoszony przezeń relatywizm moralny $\mathrm{i}$ indyferentyzm religijny nie znajduje pokrycia w jego własnym systemie. Uznając, że wszystko jest względne, siebie samego kreuje na jedyny prawdziwy światopogląd. Także idea tolerancji ulega w liberalizmie wypaczeniu. Trudno bowiem mówić o poszanowaniu odmienności, kiedy, jak zauważa S. Kowalczyk, religia zostaje wyrugowana z życia społecznego. Lubelski myśliciel jednak nie poprzestaje na wyliczeniu mankamentów ideologii liberalnej i ich waloryzacji, lecz ośmiela się zerknąć w jej przyszłe konsekwencje, które mogą być opłakane. Nieograniczona wolnośćjednostki ze swoim subiektywizmem, relatywizmem i emotywizmem prowadzi do anarchizacji życia społecznego. W powszechnym zamęcie, ludzie nie mający stałego kręgosłupa moralnego, bardzo łatwo ulec mogą pseudoautorytetom. Wnioski są więc zadziwiające - liberalizm, który wydaje się być na przeciwległym biegunie wszelkich totalitaryzmów, w rzeczywistości nieuchronnie do nich prowadzi.

\section{Bibliografia}

[1] Berlin I., Cztery eseje o wolności, Poznań 2000.

[2] Gray J., Liberalizm, Kraków 1994.

[3] Jabłoński A., Stanistawa Kowalczyka personalistyczna wizja społeczeństwa, „Roczniki Nauk Społecznych” 2012, T. 4(40), nr 1.

[4] Kowalczyk S., Człowiek a społeczność. Zarys filozofii społecznej, Lublin 1994.

[5] Kowalczyk S., Filozofia wolności, Lublin 1999.

[6] Kowalczyk S., Kim jest cztowiek?, Wrocław 1992

[7] Kowalczyk S, Liberalizm i jego filozofia, Katowice 1995.

[8] Kowalczyk S., Wolność naturą i prawem człowieka, Sandomierz 2000.

[9] Kowalczyk S., Z refleksji nad człowiekiem. Człowiek, społeczność, wartość, Lublin 1995

[10] Novak M., Liberalizm - sprzymierzeniec czy wróg Kościoła, Poznań 1991.

[11] Wojtyła K., Osoba i czyn, Lublin 2000.

34 Tenże, Z refleksji nad człowiekiem.., dz. cyt., s. 196.

35 Tamże, s. 197.

36 Tenże, Liberalizm i jego filozofia, dz. cyt., s. 211. 